\title{
Looking beyond leaves: variation in nutrient leaching potential of seasonal litterfall among different species within an urban forest
}

\author{
Sophie K. Hill' ${ }^{1}$ - Rebecca L. Hale ${ }^{1} \cdot$ Joshua B. Grinath ${ }^{1} \cdot$ Brittany T. Folk $^{1} \cdot$ Ryan Nielson $^{1} \cdot$ Keith Reinhardt $^{1}$
}

Accepted: 30 January 2022 / Published online: 25 February 2022

(c) The Author(s), under exclusive licence to Springer Science+Business Media, LLC, part of Springer Nature 2022

\begin{abstract}
Urban litterfall that is deposited on impervious surface leaches nutrients into stormwater, contributing to downstream eutrophication. Previous studies have focused on the leaching potential of deciduous leaf litter, while other smaller-volume litterfall types—-such as blossoms and fruit—may leach significant amounts of nitrogen, phosphorus, and carbon. These additional litterfall types represent an unaccounted-for source of nutrients to urban stormwater. We explored variation in leaching potential of dissolved nutrients and organic carbon across litter types and species by collecting litterfall (blossoms, fruit, leaves) from ten common urban tree species. After $24 \mathrm{~h}$ of leaching, we measured total phosphorus (TP), total dissolved nitrogen (TDN), and dissolved organic carbon (DOC) contributions and compared differences across litter types and species. Litter basket estimates then allowed us to quantify annual litterfall inputs. We found that blossoms leached 3-20 times more TDN and 1.5-7 times more TP than leaves of the same species. Furthermore, considering litterfall mass, several species had greater springtime nutrient-leaching potential compared to fall due to high leaching potential in blossoms and lower potential in leaves. We found mixed effects of leaf crushing and leachate solution (stormwater, salinity) on leaching rates. This study highlights the need to consider all litterfall types as well as variation in urban forest communities and conditions when seeking to budget, control, and maintain for potential nutrient sources from the urban forest.
\end{abstract}

Keywords Urban trees $\cdot$ Litterfall $\cdot$ Leaching $\cdot$ Nutrients $\cdot$ Blossoms

\section{Introduction}

Urban streams often contain high levels of nitrogen $(\mathrm{N})$ and phosphorus (P) from point and nonpoint sources (Walsh et al. 2005). Excess of these nutrients leads to eutrophication of downstream water bodies, with negative implications for ecosystem structure and function. While point sources of nutrients are relatively easy to identify (Howarth et al. 2000), urban nonpoint sources encompass a tremendous variety of fluxes, and quantifying contributions of each can be difficult (Groffman et al. 2004; Metson et al. 2015; Hobbie et al. 2017). Accurately identifying and quantifying these non-point sources of nutrient pollution is critical for effective management of urban forests to reduce potential fluxes.

An important non-point nutrient source to urban waters is the urban forest (Hobbie et al. 2014; Duan et al. 2014). Large

Sophie K. Hill

sophiehill842@gmail.com

1 Department of Biological Sciences, Idaho State University, Pocatello, ID, USA amounts of litterfall collect in engineered headwaters and along impervious surfaces (Fork et al. 2018), which can then leach nutrients and organic carbon into stormwater (Wallace et al. 2008; Hobbie et al. 2014; Duan et al. 2014; Selbig 2016). In some areas, autumn litterfall can contribute up to $50 \%$ of stormwater phosphorus loads annually (Selbig 2016), and in Minneapolis, MN variation in stormwater phosphorus concentrations were strongly correlated with percent urban tree canopy cover (Janke et al. 2017). While autumn leaf drop is the most obvious canopy litter flux and the main target of maintenance efforts (Baker 2014; Templer et al. 2015), other canopy litter, such as blossoms and fruit, also contribute to nonpoint source nutrient pollution (Benfield 1997; Pozo et al. 1997; Selbig 2016). Spring blossom and pollen production could explain spring pulses in stormwater nitrogen concentrations that equal those observed in autumn during leaf fall (Selbig 2016). Unfortunately, there is a notable lack of research on non-leaf litterfall nutrient inputs, even in the non-urban literature (Abelho and Graça 1996; Benfield 1997; Singh et al. 1999). Furthermore, in temperate regions, springtime litterfall occurs early in the growing season, during 
times of likely rainfall and runoff. Nutrient inputs during these times may therefore have greater impacts than those in the fall on nutrient runoff and downstream eutrophication (Essaid et al. 2021).

Moreover, our ability to predict nutrient loads from the urban canopy is complicated by significant variation in community composition across species (Morgenroth et al. 2016). Tissue nutrient content (Cobley and Pataki 2019) and the potential for litter to leach nutrients varies among species (Hobbie et al. 2014; Duan et al. 2014). Therefore, in addition to canopy cover and litter composition, the community composition of the urban forest should influence urban canopy nutrient fluxes (Wallace et al. 2008). Quantifying nutrient fluxes from the diverse urban forest therefore requires accounting for interspecific differences in nutrient leaching rates.

Finally, our ability to make accurate inferences about nutrient leaching from the urban canopy is limited by how well lab methods replicate urban conditions. Leaching is typically assessed by soaking intact leaves leached in deionized water (Dorney 1986; Wallace et al. 2008; Hobbie et al. 2014). In the urban environment, litter leaches into stormwater, which is a complex and varying chemical mixture (Pitt and Maestre 2005; Kaushal et al. 2018). Predicting stormwater litter leaching based on lab conditions is further complicated by both antagonistic and synergistic effects of the varying components of stormwater. For example, high nutrient concentrations could increase litter decomposition (Kominoski et al. 2015), while elevated salt concentrations could decrease decomposition (Cochero et al. 2017; da Silva et al. 2021; Martínez et al. 2020). Urban litterfall is also subject to physical crushing by frequent pedestrian and vehicle traffic which could increase nutrient leaching (Cowen and Lee 1973; Wang et al. 2020). Quantifying the impact of leaching solutions and physical crushing is an important step in assessing the accuracy of canopy nutrient flux estimates and potential sources of bias.

While the role of leaves as an urban nutrient source is clear, we cannot fully understand nutrient inputs from the entire urban canopy without considering differences in litter types (leaching rates, mass, and phenology), species variation, and limitations of lab methods as approximations of real-world conditions. Closer analysis of these three factors will contribute to further understanding of nutrient inputs from the urban forest. Therefore, we asked:

Q1) How do rates of nitrogen, phosphorus and organic carbon leaching vary across litter type (e.g., leaves, blossoms, and fruit) and species?

Q2) How does total potential nutrient leaching (accounting for leaching rate and litterfall volume among individual trees) vary among litter types and species?
Q3) How do common urban physical, biological, and chemical conditions, represented in the lab through manually crushing leaves and leaching in different solutions, affect leaf leaching rates?

Focusing on ten common urban tree species, we combined laboratory leaching experiments of leaves, blossoms, and fruit with a field study of litterfall rates (Table 2). We then quantified the roles of litterfall type, interspecific variation, and common lab methods on the estimated magnitude and timing of dissolved organic carbon, nitrogen, and phosphorus leaching from the urban forest.

\section{Methods}

\section{Site description}

We conducted this study in Pocatello, Idaho, USA. Pocatello is a small city covering $83.5 \mathrm{~km}^{2}$ with a population of 55,162 (US Census Bureau 2018). The city was established in 1889 during railroad development, and current city boundaries represent smaller townships now grown together. While variable across the city, average impervious cover is $42 \%$ and average tree canopy cover is 12\% (Idaho Department of Lands 2018). Community composition varies across the city and appears to be driven by several factors, with newer developments in the northeast of the city primarily containing Littleleaf Lindens (Tilia cordata) while older developments to the south are dominated by natives such as Utah Juniper (Juniperus osteosperma) and Box Elder (Acer negundo).

Pocatello is located within a larger sagebrush steppe ecosystem and has a semi-arid climate characterized by relatively wet, cold winters (DJF average temperature $-4.2^{\circ} \mathrm{C}$, average monthly precipitation $2.8 \mathrm{~cm}$ ), hot dry summers (JJA average temperature $20.8{ }^{\circ} \mathrm{C}$, average monthly precipitation $1.6 \mathrm{~cm}$ ), and total annual precipitation averaging $30.8 \mathrm{~cm}$ (NCDC 30-year avg). Pocatello is in the Portneuf River valley, between the Bannock and Portneuf Ranges, with the Portneuf River running directly through the city. The river empties into American Falls Reservoir, less than 2 miles downstream of the city, where its waters combine with the Snake River; all within the Columbia River Basin.

Surrounded by agricultural lands, Pocatello's stormflow and upstream agricultural runoff create water quality issues for the Portneuf River (Bechtold et al. 2012). The Portneuf River is regulated for total maximum daily loads (TMDLs) for both $\mathrm{N}$ and P (Ray 2010).

\section{Tree selection and litterfall collection}

To assess how leaching rates vary among species and litterfall type (Q1), we sampled blossoms, fruit, and leaves from ten 
tree species (Table 1) across Pocatello. Species were selected to represent the most common species as well as those that were likely to have distinct nutrient leaching patterns (e.g., $\mathrm{N}$-fixers). Norway Maple (Acer platinoides), Littleleaf Linden (Tilia cordata), and Siberian Elm (Ulmus pumila) were the three most common street and residential trees surveyed in 2019. Green Ash (Fraxinus pennsylvanica) was commonly planted in developments from the 1960's. Green Ash is of special interest given the looming threat of tree mortality presented by the Emerald Ash Borer, an invasive insect that has devastated urban forests in the Midwest and Eastern US (Herms and McCullough 2014) but is not yet present in Idaho. Callery Pear (Pyrus calleryana) is a cold-hardy urban tree frequently planted in commercial areas, which also produces large quantities of blossoms and fruit. Russian Olive (Elaeagnus angustifolia), an abundant invasive in some neighborhoods, and Honeylocust (Gleditsia triacanthos) have associations with $\mathrm{N}$-fixing bacteria and were expected to have higher tissue N concentrations (MacKenzie et al. 2013). Common small ornamental trees with prolific blossoms include two crabapple varieties. Malus prunifolia produces pink blossoms and larger fruit ( $1 \mathrm{~cm}$ dia.) and Malus $x$ 'spring snow' is a fruitless variety producing white blossoms. Purpleleaf Plum (Prunus cerasifera) is the only species in this study with nongreen leaves throughout the year.

Five individual trees from each of the ten species were selected for litterfall collection ( $\mathrm{n}=50$ trees total; Table 2$)$. We selected trees spatially distributed across the city (Fig. S1) to account for potential variation in growth due to slope, elevation, aspect, and homeowner fertilization and irrigation practices. While we did not sample enough trees to quantify the effects of these factors, the sampling was designed to capture the range of variability in tissue nutrient content and leaching rates.

Throughout the growing season (May-November) of 2019, samples of litterfall (i.e., blossoms, leaves, bracts, and fruit) from each of these trees $(n=50,5$ individuals from 10 species) were collected. Samples for analysis were shaken directly from the tree and stored in brown paper bags until air dried to constant weight. An early hard frost (October 9, 2019) caused Green Ash to drop leaves early, which has been shown to impact nutrient resorption in other species (Lawrence and Melgar 2018).

Five replicates of fresh grass clippings-another common coarse organic source for nutrient leaching found in gutters within our study area-were also collected directly from pavement concurrent with lawn mowing at five locations across the city. Samples were processed using tree litterfall methods and provide a qualitative comparison between blossom, fruit, and leaf leaching rates to turf grass. Lab analyses are detailed below and summarized in Table 2 .

\section{Plant tissue content}

To understand how variation in tissue content influences potential nutrients available for leaching (Q1), samples of air-dried litterfall were analyzed for percent $\mathrm{C}, \mathrm{N}$, and $\mathrm{P}$ tissue content (Table 2). Total nitrogen and carbon were obtained using methods based on McGeehan and Naylor (1988) using a Vario EL Cube system (Elementar, Langenselbold; Germany) at the Environmental Analytical Laboratory at Brigham Young University; Provo; UT. Percent phosphorus was determined using EPA method 3052; a Nitric-Hydrogen Peroxide Microwave Digestion on an

Table 1 Summary of ten common urban tree species their litterfall assessed. None of these species are native to the study region

\begin{tabular}{|c|c|c|c|}
\hline Species & $\begin{array}{l}\text { Common Name } \\
\text { and Abbreviation }\end{array}$ & Litterfall Collected & Unique Properties \\
\hline Malus prunifolia & Plumleaf Crabapple (CAP) & Blossoms, fruit, and leaves & Pink blossom pigment \\
\hline $\begin{array}{l}\text { Malus } x \\
\text { 'spring snow' }\end{array}$ & $\begin{array}{l}\text { 'Spring snow' Crabapple } \\
\text { (CAW) }\end{array}$ & $\begin{array}{l}\text { Blossoms and leaves, } \\
\text { non-fruiting variety }\end{array}$ & White blossom pigment, fruitless \\
\hline Pyrus calleryana & Callery Pear (CP) & Blossoms, fruit, and leaves & $\begin{array}{l}\text { Cold-hardy and drought tolerant, common in } \\
\text { commercial lots }\end{array}$ \\
\hline Fraxinus pennsylvanica & Green Ash (GA) & $\begin{array}{l}\text { Fruit and leaves, small blossoms }(<3 \mathrm{~mm}) \\
\text { not leached or collected }\end{array}$ & $\begin{array}{l}\text { Very common and threatened by invasive } \\
\text { insects }\end{array}$ \\
\hline Gleditsia triacanthos & Honeylocust (HL) & $\begin{array}{l}\text { Blossoms and leaves, } \\
\text { non-fruiting variety }\end{array}$ & $\mathrm{N}$-fixer, fruitless \\
\hline Prunus cerasifera & Purpleleaf Plum (PP) & $\begin{array}{l}\text { Blossoms and leaves, } \\
\text { non-fruiting variety }\end{array}$ & $\begin{array}{l}\text { Non-green leaves } \\
\text { year-round, fruitless }\end{array}$ \\
\hline Tilia cordata & Littleleaf Linden (LL) & $\begin{array}{l}\text { Bracts and leaves, blossom mass was } \\
\text { measured but not leached }\end{array}$ & $\begin{array}{l}\text { Bracts, second most } \\
\text { common tree in city }\end{array}$ \\
\hline Acer platinoides & Norway Maple (NM) & Blossoms, fruit, and leaves & Most common tree in city \\
\hline Elaeagnus angustifolia & Russian Olive (RO) & Blossoms, fruit, and leaves & $\mathrm{N}$-fixer, invasive \\
\hline Ulmus pumila & Siberian Elm (SE) & $\begin{array}{l}\text { Fruit and leaves, small blossoms }(<3 \mathrm{~mm}) \\
\text { not leached or collected }\end{array}$ & $\begin{array}{l}\text { Spring fruit, } \\
\text { very common volunteer species }\end{array}$ \\
\hline
\end{tabular}


Table 2 Summary of the methods and analyses used throughout this study

\begin{tabular}{|c|c|c|c|}
\hline $\begin{array}{l}\text { Research } \\
\text { Question }\end{array}$ & Analysis & Brief Methods & Number of Samples \\
\hline 1 & Litterfall Tissue Content & $\begin{array}{l}\text { Dried litter sample ground and analyzed for } \% \\
\mathrm{C}, \mathrm{N} \text {, and } \mathrm{P}\end{array}$ & $\begin{array}{l}\sim 3 \text { litter types per } 5 \text { trees, per } 10 \text { species } \\
(\mathrm{n} \sim 150)\end{array}$ \\
\hline 1 & Nutrient Leaching Potential & Dried litter leached for $24 \mathrm{~h}$ in deionized water & $\begin{array}{l}\sim 3 \text { litter types per } 5 \text { trees, per } 10 \text { species } \\
(\mathrm{n} \sim 150)\end{array}$ \\
\hline 2 & Total Nutrient Flux & $\begin{array}{l}\text { Litter baskets to estimate litter mass, multiplied } \\
\text { by tissue } \% \mathrm{C}, \mathrm{N} \text {, or P }\end{array}$ & $\begin{array}{l}\sim 3 \text { litter types per } 3-5 \text { trees per } 10 \text { species. } \\
(\mathrm{n} \sim 120)\end{array}$ \\
\hline 2 & Total Nutrient Leaching Potential & $\begin{array}{l}\text { Litter baskets to estimate litter mass flux, } \\
\text { multiplied by average leaching rate }\end{array}$ & $\begin{array}{l}\sim 3 \text { litter types per } 3-5 \text { trees per } 10 \text { species. } \\
(\mathrm{n} \sim 120)\end{array}$ \\
\hline 3 & Stormwater & $\begin{array}{l}\text { Dried litter leached for } 24 \mathrm{~h} \text { in collected } \\
\text { stormwater }\end{array}$ & Only Norway maple leaves, 1 per tree, $(n=5)$ \\
\hline 3 & Crushing & $\begin{array}{l}\text { Dried litter manually crushed and then leached } \\
\text { for } 24 \mathrm{~h} \text { in deionized water }\end{array}$ & Only leaves, 1 per tree, 6 species $(n=29)$ \\
\hline 3 & Salt & $\begin{array}{l}\text { Dried litter leached in } 0,1.5,3 \text {, or } 6 \mathrm{mg} \mathrm{Cl} / \mathrm{L} \\
\text { salt solution and sampled periodically over } \\
128 \mathrm{~h} \text {, solution replaced after each sampling }\end{array}$ & $\begin{array}{l}\text { Only Norway Maple leaves from a single tree, } \\
3 \text { replicates per salt concentration }(n=12 \times 5 \\
\text { timestamps) }\end{array}$ \\
\hline
\end{tabular}

Ethos EZ system (Milestone, Shelton, CT; USA), followed by ICP-OES Analysis using the iCAP 7400 system (Thermo Electron, Madison, WI; USA), also at BYU. All tissue measurements are reported as a percent of dry mass.

\section{Leaching methods}

To understand how leaching rates vary across litter types among the different species (Q1), intact, air-dried samples (5 replicates per species) were placed in 1-L high density polyethylene (HDPE) bottles at a ratio of $1 \mathrm{~g}$ of litterfall to $100 \mathrm{~mL}$ of deionized water, generally equating to $5 \mathrm{~g}$ of dried sample to $500 \mathrm{~mL}$ water (Table 2). Dried samples selected for leaching were fully intact with no visible signs of decomposition. After inundation, samples were overturned ten times before resting for $24 \mathrm{~h}$ at room temperature $\left(22^{\circ} \mathrm{C}\right)$. After $24 \mathrm{~h}$, samples were again overturned ten times and unfiltered leachate was removed for total phosphorus (TP) analysis. Remaining leachate sample was then filtered through ashed Whatman A pre-filters to eliminate large particulates, followed by ashed Whatman GF/F $(0.7-\mu \mathrm{m}$ pore $)$ filters. Filtered and unfiltered samples were kept frozen at $-18{ }^{\circ} \mathrm{C}$ until analysis at the Environmental Analysis Lab in Brigham Young University; Provo, Utah.

Samples for total dissolved nitrogen (TDN) and dissolved organic carbon (DOC) were analyzed on a Shimadzu TOC/ TN analyzer at the Environmental Analysis Lab at Brigham Young University (detection limit $=0.07 \mathrm{mg} \mathrm{N} \mathrm{L}^{-1} \mathrm{TDN}$ and $0.2 \mathrm{mg} \mathrm{C} \mathrm{L}^{-1} \mathrm{DOC}$ ). TP was analyzed using a Thermo Scientific iCAP 7400 system (Madison, WI; USA).

All leaching rates ( $\mathrm{mg} \mathrm{N}$ or $\mathrm{P}$ or DOC $\mathrm{g}^{-1}$ dry mass day ${ }^{-1}$ ) were calculated by multiplying reported leachate concentrations (mg N or P or DOC $\mathrm{L}^{-1}$ ) by the concentration of litter
( $\mathrm{mL}$ deionized water $\mathrm{g}^{-1}$ sample) taken over $24 \mathrm{~h}$ of leaching time. While exact litter amounts varied, concentrations were held at a ratio of $1 \mathrm{~g}$ of litterfall to $100 \mathrm{~mL}$ deionized water.

\section{Litter baskets}

To explore how timing and magnitude of litter drop varies across species and thus the litterfall available for leaching (Q2), we measured the quantity of dropped litterfall using litter baskets deployed beneath urban trees from May-November 2020 (Table 2). Due to the COVID-19 pandemic, tree selection differed from those targeted for leaching (Fig. S1), and access was limited, but a minimum of two and maximum of five baskets were deployed per species. At each tree, a single basket (measuring $39 \times 55 \mathrm{~cm} ; 0.21$ $\mathrm{m}^{2}$ ) was placed beneath the tree canopy, generally near the trunk for accessibility. Baskets were fitted with a fine mesh which was collected weekly and remained deployed from first until final litter drop. Baskets were periodically removed between litterfall pulses (e.g., between spring blossoms and fall leaves) for security and logistics. Samples were air-dried and weighed to provide an approximate mass of litterfall deposited per $\mathrm{m}^{2}$ of litter basket which serves as a proxy for tree canopy.

Litter baskets did not capture Green Ash blossoms. Green Ash are dioecious, and litter baskets for seed/leaf collection were deployed only under female trees to capture abundant fruit. Furthermore, Ash Flower Gall (Wawrzynski and Ascerno 1989) is a common condition in our area which leads to woody scales surrounding male blossoms and causes blossoms to be retained for multiple years. Due to the small size of ash blossoms $(<3 \mathrm{~mm})$ and an inability to predict this condition ahead of litterbasket deployment, Green Ash blossoms were not captured in our study. 
We were also unable to capture Siberian Elm blossoms, which are less than $3 \mathrm{~mm}$ across and do not have petals. Siberian Elms produce abundant papery fruit each spring that are wind dispersed long distances from the mother tree. Given the tall vase-like structure of a mature Siberian Elm and Idaho's strong springtime winds, our initial litter basket assessment (spring 2020) greatly underestimated the mass of Siberian Elm fruit as they were often carried and deposited well-beyond our baskets into nearby streets and neighboring parcels. An additional assessment was conducted in spring 2021 targeting shorter and unpruned elm trees which provided more successful seed collection. Those results were used in estimating Siberian Elm seed loads.

Combining leaching estimates with litterfall measurements provides a first cut at estimating nutrient leaching inputs from the urban canopy. While our litter basket survey was not designed to evaluate tree size, canopy volume, irrigation practices, annual shifts in phenology, or growing conditions, efforts were made to account for these factors whenever possible. Trees selected were established $(>5 \mathrm{~m}$ tall) and approximately the same size with duplicates at a site being used whenever possible. Otherwise scaling up our leaching estimates using methods such as allometric relationships is challenging in urban environments (McHale et al. 2009). Urban trees are subject to a variety of growing conditions (McPherson and Peper 2012), maintenance and care, and are often heavily pruned-all of which can impact tree growth (Fini et al. 2015). Furthermore, it is recommended that allometric equations be location-dependent for accuracy (Jara et al. 2015). While some data does exist for urban trees (McPherson et al. 2016) they do not include all species and, importantly, not all litterfall types used in our study. All the trees used for basket placement—often located near streets and along parking lots-showed signs of pruning. Although limited by factors such as wind, vandalism, the COVID-19 pandemic, and other placement restrictions, our litter basket survey provides a coarse but useful firstorder estimate of potential litterfall across our city.

\section{Salt leaching}

We tested the impacts of salt on total dissolved nitrogen (TDN) and dissolved organic carbon (DOC) leaching (Q3) on a subset of Norway Maple leaves from a single tree (Table 2). This exploratory study focused on this species since it is a common urban tree species. Leaves were harvested from a single tree to minimize variation in litter nutrient content, and $\mathrm{NaCl}$ was used to make four $\mathrm{Cl}^{-}$treatments: $0 \mathrm{~g} \mathrm{Cl}^{-} \mathrm{L}^{-1}, 1.5 \mathrm{~g} \mathrm{Cl}^{-} \mathrm{L}^{-1}, 3 \mathrm{~g} \mathrm{Cl}^{-} \mathrm{L}^{-1}$ and $6 \mathrm{~g} \mathrm{Cl}^{-} \mathrm{L}^{-1}$, where the highest $\mathrm{Cl}^{-}$concentration corresponded to the maximum observed stormwater conductivity in Pocatello (unpublished data). Three replicates of three grams of airdried leaves were leached in $500 \mathrm{ml}$ of treatment solution in 1-L HPDE bottles and an additional blank without leaves (leaf mass was limited by the amount of material available for the number of treatments and replicates). Samples were collected at 3, 27, 51, 97, and $219 \mathrm{~h}$. At each sampling point, the entire solution was poured off and filtered through ashed Whatman GF/F (0.7- $\mu \mathrm{m}$ pore) filters and frozen until analysis, and a fresh solution of the same $\mathrm{NaCl}$ concentration was added to the bottle. Samples were frozen until analysis and analyzed for DOC and TDN as above at BYU.

\section{Stormwater collection}

To compare leaching potential in stormwater (Q3) and distilled water, we collected stormwater directly from the pipe at an outfall during an event on March 14, 2020. This outfall drained a $\sim 5 \mathrm{~km}^{2}$ including many of the sampled tree locations. At the time of sampling, gutter flow had persisted for several hours, so this stormwater likely did not represent first-flush concentrations. As this portion of our study was primarily exploratory, we did not make efforts to capture water representative of an entire storm, nor did we have sufficient litterfall to fully replicate it across all species and litter types. We replicated our previous intact leaf leaching methods on a single speciesNorway Maple, the most common tree $(n=5$; Table 2$)$ - using stormwater in place of distilled water. In addition to leachate samples, we analyzed the raw stormwater for the same suite of analytes, including DOC $\left(9.83 \mathrm{mg} \mathrm{L}^{-1}\right)$, TDN $\left(0.88 \mathrm{mg} \mathrm{L}^{-1}\right)$, and TP $\left(0.21 \mathrm{mg} \mathrm{L}^{-1}\right)$ as well as a complete ICP analysis. The highest concentrations were salt components, including $\mathrm{Cl}\left(45.52 \mathrm{mg} \mathrm{L}^{-1}\right), \mathrm{Na}\left(38.03 \mathrm{mg} \mathrm{L}^{-1}\right)$, and $\mathrm{Ca}\left(14.54 \mathrm{mg} \mathrm{L}^{-1}\right)$.

\section{Crushing methods}

To assess the impact of physical crushing on leaf leaching potential (Q3), we included a crushing treatment for leaf replicates of six species ( $\mathrm{n}=29$; Table 2) including Norway Maple (Acer platinoides), Littleleaf Linden (Tilia cordata), Siberian Elm (Ulmus pumila), Russian Olive (Elaeagnus angustifolia), Honeylocust (Gleditsia triacanthos), and Green Ash (Fraxinus pennsylvanica). We did not have sufficient leaf litter to assess impacts of crushing on all 10 species. Dried litter was crushed by manually forcing it through the $1-\mathrm{cm}$ opening of an acid-washed HDPE funnel placed over a 1-L HDPE bottle. A pre-measured amount of ultra-pure water was used to rinse the funnel directly into the inundation bottle. This approach ensured that no mass of pre-weighed leaf sample was lost. Crushed samples were then leached following the same protocol used for intact leaves (see 2.4).

\section{City-wide scaling estimates}

To approximate city-wide leaching potential, we used a newly created inventory of $\sim 39,000$ residential and street 
trees and a 2018 state-wide analysis of urban canopy cover and impervious surface area by the Idaho Department of Lands (Idaho Department of Lands (IDL) 2018). Given our focus on urban tree impacts on stormwater quality, we limited our study to tree canopy directly over impervious surface To calculate city-wide canopy cover by species, Thiessen polygons - whose borders are defined by the midpoint between points-were created surrounding each surveyed tree using ArcPro software. This approximated each individual tree canopy extent within continuous sections of canopy cover. These polygons were intersected with the IDL urban canopy dataset and then trimmed to that immediately above impervious surface-defined as streets and parking lots. This provided us with a city-wide species-level canopy cover estimate over impervious surface. When possible, these areas were multiplied by the calculated leaching potential for our 10 targeted species. Leaching potential of unmeasured species were estimated using the minimum and maximum annual leaching potential of the measured species, creating a bracketed range of estimates.

\section{Analysis}

We used R programing software Version 4.0.3 to run all analysis (R Core Team 2020). Figures were designed using 'ggplot2' (Wickham 2016). Throughout our analysis, we used $\alpha=0.05$ to determine statistical significance and Type II SS for unbalanced data.

To assess Q1, we compared leaching rates among litterfall type (blossoms, fruits, and leaves) using linear mixedeffects models (LMMs) with 'species' as the random factor (varying intercepts). We used the 'Imer' ('Ime4'; Bates et al. 2015) and 'Anova' ('car'; Fox and Weisberg 2019) functions in $R$ to conduct our analyses. Results are presented using Wald's chi-square test statistics. We then used Tukey's HSD for post-hoc comparisons among litter types, using the 'emmeans' package (Lenth 2020). Separate models were assessed for leaching rates of TDN, TP, and DOC, as well as plant tissue content of N, P, and C. We were also interested in understanding if differences in litter tissue content explained variation among litter types, yet we were unable to use ANCOVA because the range of values for the covariates differed greatly among the litter types, which violates model assumptions. Therefore, we fit nine separate linear models relating leaching rate and tissue nutrient content for TDN, TP, and DOC by each litter type (blossoms, leaves, fruit) and compared these regressions qualitatively. While our focus was on differences in litterfall types, we anticipated interspecific differences in responses, which we interpreted qualitatively. Species was included as a random effect in the LMMs, as not all species had all litterfall types (i.e., these variables were not fully crossed.)
To assess Q2, litter basket results were scaled up by multiplying minimum, mean, and maximum leaching rates by the average litter basket mass for each litter type and species for each week. We then totaled the litterfall mass across time for each litter type and species within each replicate basket and multiplied these mass totals by their corresponding leaching rate to calculate potential total TDN, TP, and DOC leaching. We used average litterfall mass as minimum and maximum litterfall rates ranged widely due to tree size variation. To compare among litter types and species, we summed the total nutrient leaching potential across the study period for each litter type and species. We could not statistically test differences between tree species and their total nutrient leaching potential because litterfall and leaching estimates did not use the same individual trees for each species.

To assess Q3, we used linear regression to assess how salt concentrations affect leaching rates and Welch's 2-sample $\mathrm{t}$-test to compare leaching rates between stormwater and DI water due to unequal variances. Because we included several species in our crushing experiment, we used a LMM with crushing as a fixed effect and species as a random effect, similar to above. Residuals of all analyses were visually inspected to confirm that the data met model assumptions.

\section{Results}

\section{Leaching rates across litter type and species}

Leaching rates of TDN, TP, and DOC varied up to sevenfold among blossoms, fruit, and leaves after $24 \mathrm{~h}$ of leaching (Fig. 1). There were significant differences in leaching rates among litterfall types for all analytes (Table S1), and these differences were consistent among species (Fig. 1). For both TDN and DOC, leaching rates were greatest for blossoms, intermediate for leaves, and lowest for fruit. The leaching rate of TP was greater for blossoms than both leaves and fruit, which did not differ from each other. Among species, TDN leaching from blossoms was 3-20 times greater than that of leaves. TP leaching from blossoms was 1.5-8 times more than from leaves of the same species. TDN and TP leaching rates from fresh grass clipping were similar to tree blossoms (Fig. S2), while DOC leaching rates from grass was similar to that of tree leaves. Bract litter was only present in Littleleaf Linden (Tilia cordata) and was associated with relatively low levels of TDN, TP, and DOC leaching (Fig. S2).

Despite variation in leaching rates among species (Fig. 1), the pattern of higher TDN and TP leaching from blossoms and lowest leaching from fruit was consistent among species. For example, for all species with available data, blossoms leached more than other litter types, despite two-fold variation among species in blossom TDN leaching rates. Fruit leaching 

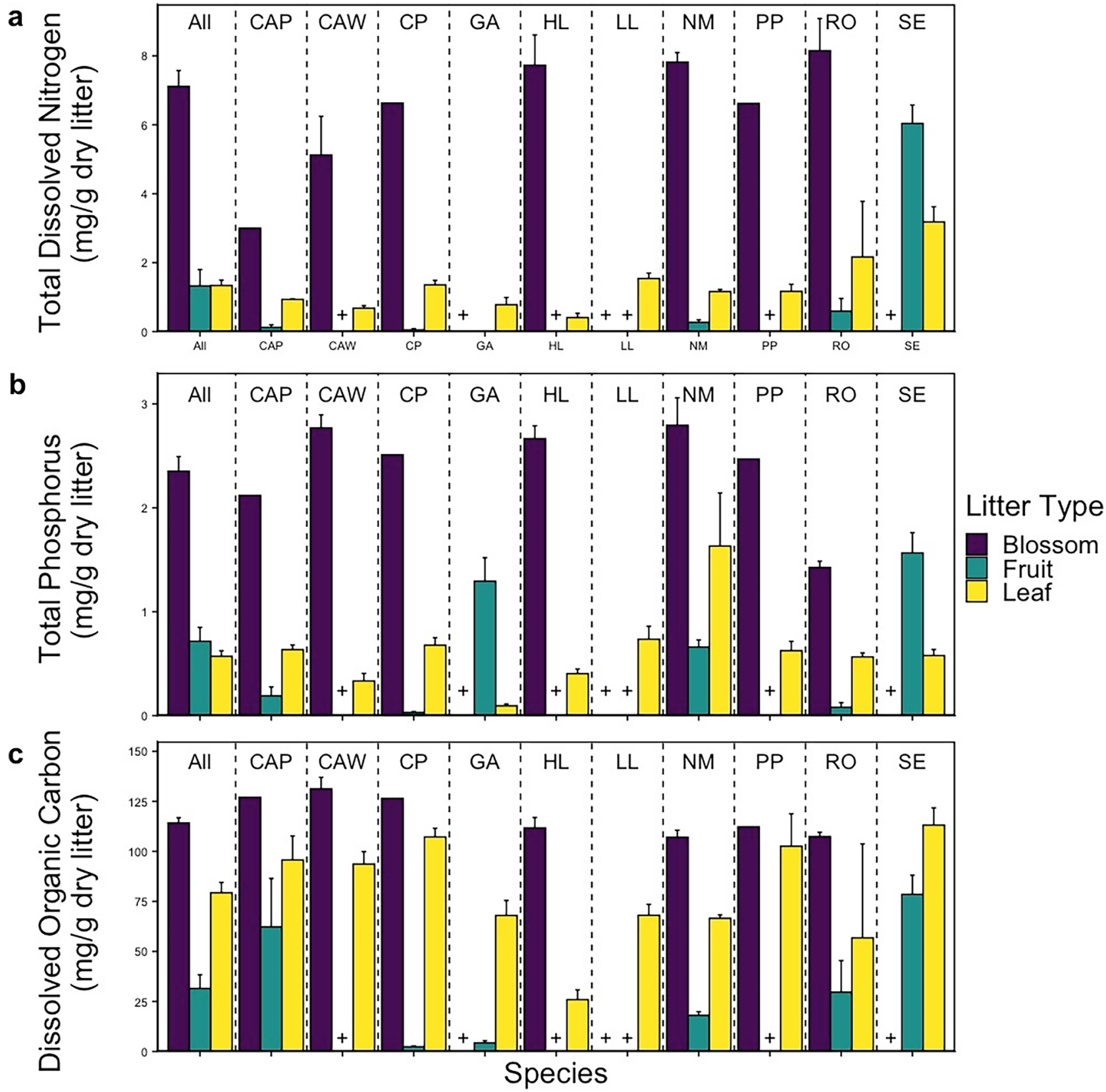

Fig. 1 Mean ( \pm 1 SE) leaching rates among species and litter type for a) TDN, b) TP, and c) DOC. "+" indicates no data as it was either not collected or the species does not produce that tissue type (See Table 1). Blossoms leached significantly for all analytes (LMM; TDN: $\chi^{2}=311.53, p<0.0001$; TP: $\chi^{2}=215.05, p<0.0001$; DOC: $\chi^{2}$ $=169.58, p<0.0001)$ Blossoms leached significantly more TDN and

patterns were consistently lower except for Siberian Elm fruit, which leached up to eight times more than any other fruit and at levels approaching the average leached by blossoms. This amount was still double the rates of TDN and TP leached by Siberian Elm leaves. Green Ash fruit also leached seven times more TP compared to its leaves but in contrast, its fruit leached an undetectable amount of TDN over the 24-h period.
TP than leaves and fruit (Tukey HSD, $p<0.05$ ); while DOC leaching was greatest from blossoms and lowest from fruit (Tukey HSD, $p<0.05)$. Species Abbreviations-All: All species; CAP: Plumleaf crabapple; CAW: 'Spring snow' crabapple; CP: Callery Pear; GA: Green Ash; HL: Honeylocust; LL: Littleleaf Linden; NM: Norway Maple; PP: Purpleleaf Plum; RO: Russian Olive; SE: Siberian Elm

\section{Litter tissue content and leaching rates}

Plant tissue content varied significantly among litter types for all analytes (Table S3: LMM; TDN: $\chi^{2}=18.46$, $p<0.0001$; TP: $\chi^{2}=145.26, p<0.0001$; DOC: $\chi^{2}=191.9$, $p<0.0001$ ) with the highest $\mathrm{N}$ and $\mathrm{P}$ in blossoms compared to fruit and leaves. Species associated with $\mathrm{N}$-fixing 
symbionts (HL and RO) had some of the higher tissue $\mathrm{N}$ content of all species in both leaves and blossoms while still falling within the range of other non-N fixing species. Leaf tissue content also differed substantially between the two $\mathrm{N}$-fixing species (Fig. S3), suggesting that species variation may be more important than $\mathrm{N}$-fixer status.

Tissue content and leaching rates were consistently higher in blossoms and lower in leaves, and for any given tissue content, blossoms consistently leached TDN, TP, and DOC at higher rates than leaves and fruit (Fig. 2; Table S2). TDN and TP leaching rates were significantly and positively related to tissue content in both blossoms and fruit while DOC leaching in fruit and leaves showed a significant negative relationship with tissue content (Fig. 2). In contrast, TDN and TP leaching in leaves was unrelated to tissue content (Fig. 2). The positive relationship between tissue content and leaching rate in fruit was driven by Siberian Elms which had relatively high $\mathrm{N}$ and $\mathrm{P}$ tissue content as well as leaching rates; when these data were excluded, there was no relationship (Fig. S4; Table S2).

\section{Litter basket assessment of mass of litterfall by type and species}

Urban trees dropped $120-1500 \mathrm{~g} \mathrm{~m}^{-2}$ of litterfall annually, when aggregated across all litter types. Litterfall mass varied
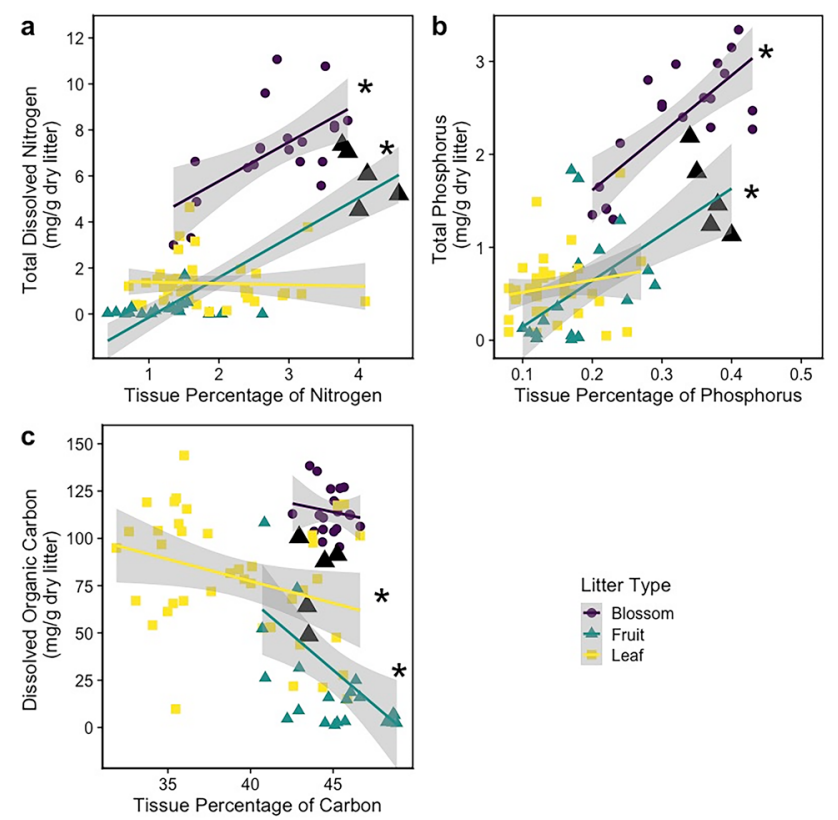

Fig. 2 Relationships between leaching rates and tissue content differed when aggregated across litter types (See LM, Table S3). The larger black triangles indicate Siberian Elm fruit which had higher tissue concentrations and leaching rates compared to all other fruit and drove positive relationships between leaching and content (See Fig. S3 and Table S3). “*” denotes statistical significance of the slope with shaded areas representing $95 \%$ confidence intervals among litter type (LMM; $\left.\chi^{2}=19.33, p<0.001\right)$. For most species, leaf litter and fruit fall were the largest total litter flux - up to five times the mass of blossoms (Fig. 3a, b). Exceptions were Littleleaf Linden, which had similar litterfall rates for blossoms and leaves, and Russian Olive, which had similar rates for blossoms and fruit (Fig. 3a, b). Total annual blossom fall mass ranged from $25-150 \mathrm{~g} \mathrm{~m}^{-2}$ among species, while total leaf fall mass ranged from 120-400 $\mathrm{g} \mathrm{m}^{-2}$ among species. When present, fruit inputs were similar in magnitude to leaf inputs and represented between $30 \%$ (RO) and 80\% (CAP) of total litterfall mass.

The seasonal distribution of litterfall also varied among species and litter types. Litterfall mass was dominated by fall inputs for some species (i.e., Crabapples, Green Ash, Norway Maple). Litterfall from other species was more evenly distributed between spring and fall inputs (i.e., Honeylocust, Russian Olive). Still others dropped litter over an extended period. For example, Littleleaf Linden dropped litter continually for almost six months as a mixture of blossoms, bracts, and fruit, at times all three simultaneously (Fig. 3a).

Even with the lower total mass of spring litterfall, potential leaching fluxes from blossoms $\left(\mathrm{mg} \mathrm{m}^{-2}\right.$ week $^{-1}$, based on leaching rates and litterfall fluxes) approached or exceeded autumn rates from fruit and leaves in several species (Figs. 3a, c, S5 and S6). Species with especially high nutrient leaching from blossoms, such as Honeylocust and 'Spring Snow' Crabapple, had potential nutrient leaching signatures dominated by springtime inputs (Fig. 3c). In contrast, species with large leaf fall and moderate to high potential rates of leaf litter leaching-such as Green Ash and Callery Pear-had potential nutrient leaching signatures dominated by autumn inputs.

Seasonal patterns in potential nutrient leaching between TDN and TP were similar, but not identical (Fig. S5). For example, fruit from the Green Ash leached undetectable amounts of TDN but substantial amounts of TP, leading to its "dual-peak" autumn signature in potential TP leaching. Norway Maple fruit and leaves drop in enormous quantities and both leached substantial amounts of TP to shift its potential leaching signature to autumn-dominated inputs. Overall, total potential DOC leaching patterns followed a similar pattern to litterfall mass (Fig. S6).

\section{Total litterfall nutrient leaching among species}

Total annual litterfall combined with leaching potential allowed us to identify "problem species" that potentially contribute disproportionately to nutrient leaching in urban areas (Fig. 4). The top contributing species varied depending on the analyte of interest. Norway Maple, Plumleaf crabapples, and Callery Pear were all highly ranked for total potential DOC, TDN, and TP leaching. 


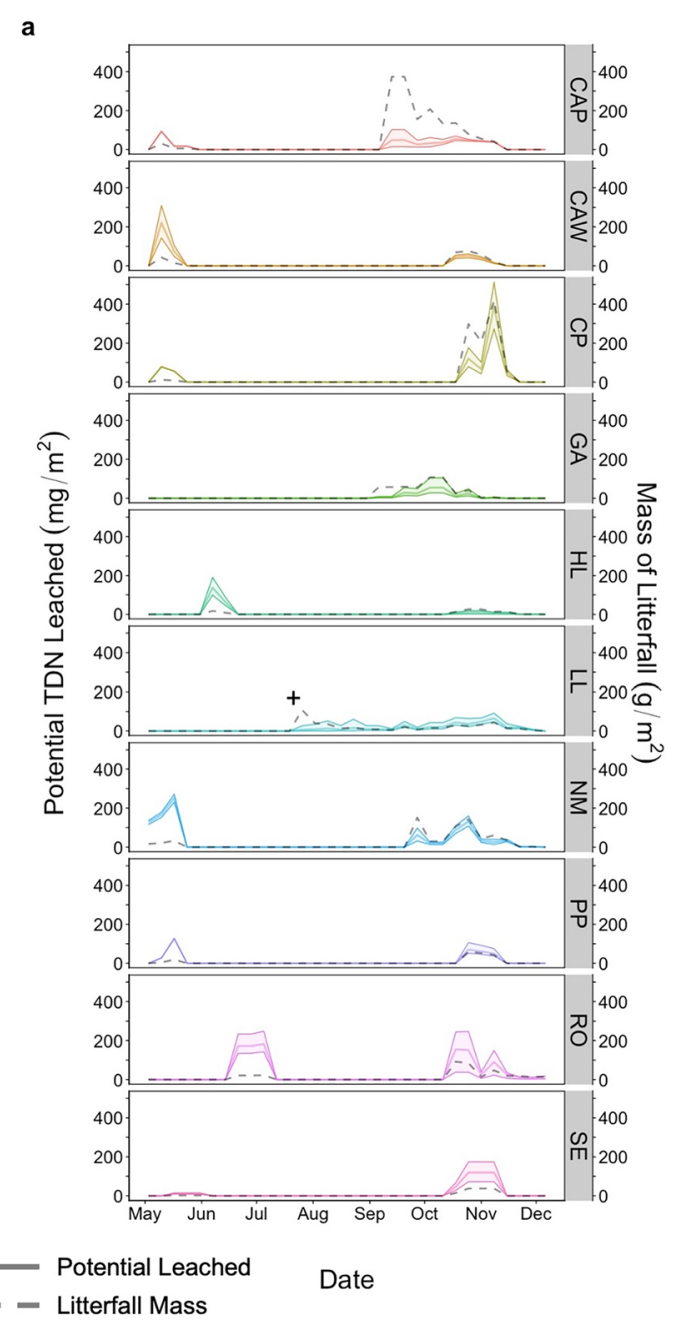

Fig. 3 a) Potential Total Dissolved Nitrogen (TDN) leached based on average weekly mass collected in litter baskets and potential leaching rates. Dashed gray lines represent the average mass of litterfall in $\mathrm{g} \mathrm{m}^{-2}$ week $^{-1}$. Solid bold lines indicate average potential leached (mean litterfall mass multiplied by mean leaching rates) while thinner lines represent estimates based on maximum and minimum leaching rates. b) Average ( $\pm 1 \mathrm{SE})$ total mass of litterfall by lit-

Russian Olive, a common invasive species in the western United States and symbiotic $\mathrm{N}$-fixer, was the primary offender for potential TDN leaching, but was in the bottom $50 \%$ for TP. Similarly, Green Ash had the lowest potential TDN leaching, but has a high potential to contribute TP.

Estimated annual nutrient fluxes from urban forest litterfall normalized by total city area yields estimates of 1000-3000 kg C ha- ${ }^{-1}$ year $^{-1}, 50-100 \mathrm{~kg} \mathrm{~N} \mathrm{ha}^{-1}$ year $^{-1}$, and 5-15 kg P ha ${ }^{-1}$ year $^{-1}$ (Fig. 5). Leaching potential of nutrients from litterfall after $24 \mathrm{~h}$ of inundation was less than $1 \%$ that of total nutrient flux estimates (Fig. 5; panels d-f). Leaching flux estimates were $1-5 \mathrm{~kg} \mathrm{C} \mathrm{ha}^{-1}$ year $^{-1}$, 1-15 $\mathrm{g} \mathrm{N}^{-1}$ year $^{-1}$, and 5-15 mg P ha ${ }^{-1}$ year $^{-1}$.
C

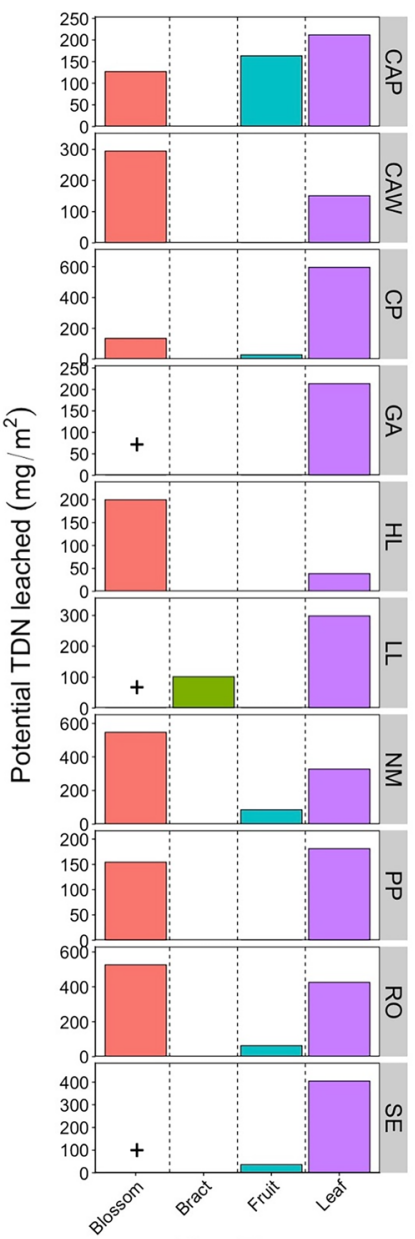

Litter Type

ter type summed $\left(\mathrm{g} \mathrm{m}^{-2}\right)$ by species. c) Average $( \pm 1 \mathrm{SE})$ potential TDN leached $\left(\mathrm{mg} \mathrm{m}^{-2}\right)$ by litter type and species. Similar figures for TP and DOC can be found in supplemental materials. "+" indicates missing data. CAP: Plumleaf crabapple; CAW: 'Spring snow' crabapple; CP: Callery Pear; GA: Green Ash; HL: Honeylocust; LL: Littleleaf Linden; NM: Norway Maple; PP: Purpleleaf Plum; RO: Russian Olive; SE: Siberian Elm

\section{Replicating urban conditions in the lab}

Norway Maple leaf leaching rates in stormwater were not significantly different from those leached in deionized water across all analytes (Fig. S7). In contrast, salt concentration significantly decreased DOC (but not TDN) leaching over the 9-day experiment (Fig. S8). In general, across species, crushing leaves increased leaching rates for all analytes (Fig. S9, LMM; TDN: $\chi^{2}=11.20, p<0.01$, TP: $\chi^{2}=9=8.50, p<0.01$, DOC: $\chi^{2}=39.70$, $p<0.001$ ) increasing mean leaching rates by $60 \%$ for TDN, $72 \%$ for TP, and $67 \%$ for DOC. However, the effect of crushing varied substantially among species. Crushing had no effect on TDN leaching for Norway Maple, but increased TDN leaching 0.7 times for Green Ash. Crushing increased TP leaching rated by 


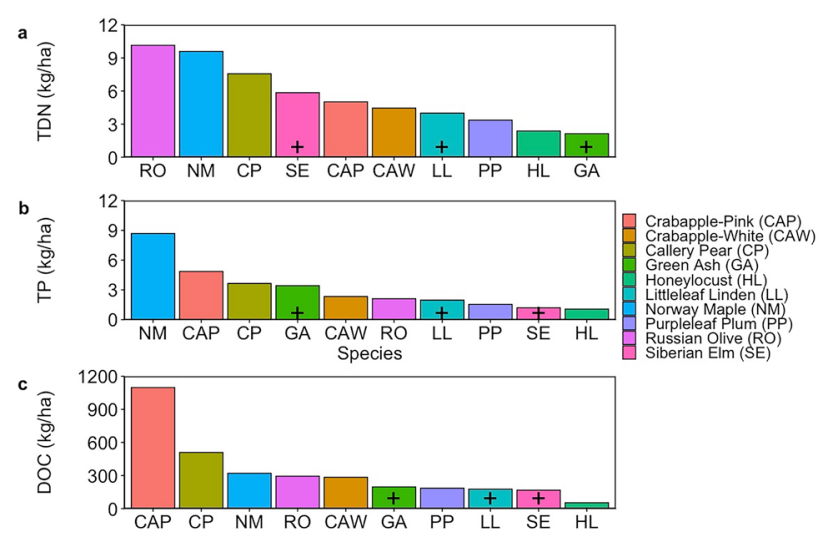

Fig. 4 Total potential TDN, TP, and DOC leached by litterfall based on mass (Fig. 3b) and potential leaching across litterfall types (Fig. 3c) for 10 species of urban tree. Values have been normalized by canopy extent. Norway Maple (NM) and Callery Pear (CP) both occur in the top three species leached across all analytes, while other species (GA, SE, RO) vary widely in their potential leaching depending on analyte being considered. "+" indicates underestimates as not all leaching data was available for those species (see Table 1)

near-zero (LL, NM, RO, SE) to 16 times in Green Ash. Crushing increased DOC leaching rates from near zero (Norway Maple) to 3.8 times in Honeylocust (Fig. S9; Table S4).
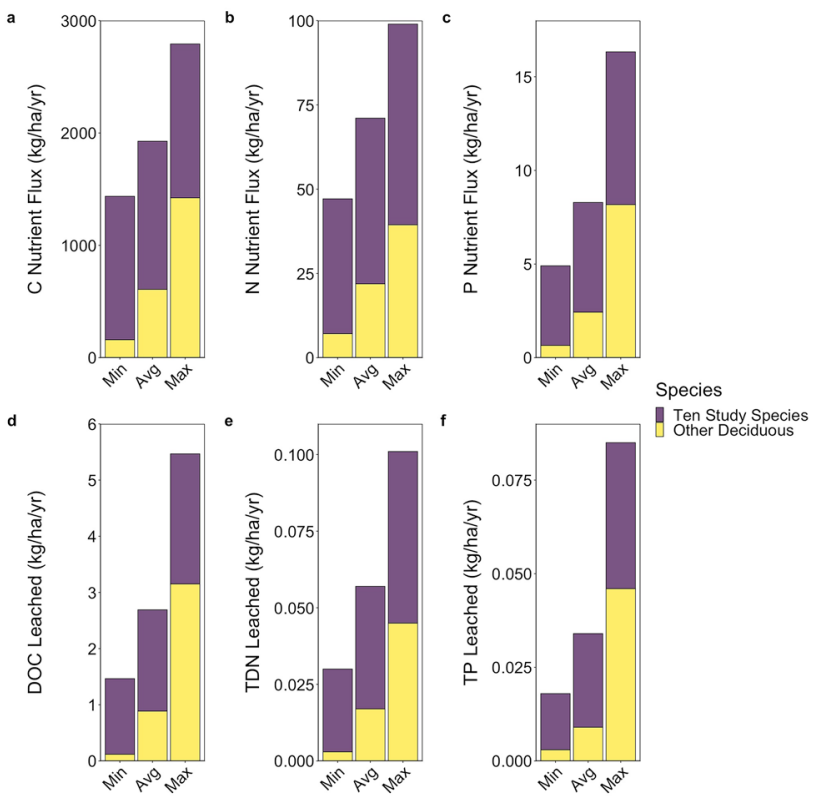

Fig. 5 Estimated annual city-wide fluxes and leaching potential from all litterfall. a-c indicate nutrient and carbon fluxes based on mass and $\% \mathrm{C}, \mathrm{N}$, or P. Values for "other deciduous" were estimated from average, minimum, and maximum tissue percentages multiplied by litterfall masses of the ten species gathered. This creates a bracketed range for our estimates due to unmeasured species. No conifer estimates were made due to a lack of information on litterfall rates and appropriate leaching rates. Panels d-f show potential leaching from litterfall inputs based on mass leached after $24 \mathrm{~h}$. Values for "other deciduous" were estimated using the same method as described for panels a-c

\section{Discussion}

\section{Urban tree blossom fall is a major potential nutrient flux in cities}

Urban blossom fall represents an unappreciated source of dissolved nutrients. Blossom tissue had higher N, P, and C content compared to leaves and fruit, and a greater proportion of tissue nutrients leached from blossoms. Leaching rates from blossoms were consistently greater than leaves and fruit of the same species. Despite the small mass flux of blossoms relative to leaves, high leaching rates meant that total seasonal potential leaching from blossoms approached, or exceeded, that of autumn leaves across several species. As a result, historic studies focusing exclusively on nutrient and carbon fluxes associated with leaf fall (Cowen and Lee 1973; Meyer 1980; Dorney 1986; Bratt et al. 2017) may be neglecting a critical nutrient flux, across both urban and non-urban ecosystems. Non-leaf litterfall appears to constitute a significant urban nutrient flux that has thus far gone unaccounted in urban nutrient budgets (Groffman et al. 2004; Metson et al. 2015; Hobbie et al. 2017). For example, potential areal nitrogen inputs from Russian Olive and Normal Maple in our study area approach rates of atmospheric $\mathrm{N}$ deposition inputs and total export from urban watersheds (Groffman et al. 2004). Our city-wide analysis-limited to urban tree canopy overhanging a subset of impervious surface-showed that urban litterfall nutrient fluxes represent a substantial internal nutrient flux (e.g., 5-10 times suburban $\mathrm{N}$ fertilizer inputs, Groffman et al. 2004). Considering that Pocatello has relatively low canopy cover compared to other cities (12\%), these fluxes are likely to be substantially higher in other urban areas.

\section{Species diversity impacts nutrient leaching potential both spatially and temporally}

Considering all litter inputs, potential nutrient leaching per gram of dry litter varied up to five-fold among the 10 urban species we studied, supporting earlier findings that leaching varies among species (Cowen and Lee 1973; Dorney 1986; Wang et al. 2007; Hobbie et al. 2014). Importantly, some species had the potential to contribute substantially to one nutrient, but not to others (e.g., Russian Olive had high N, but low P leaching potential), while species such as Norway Maple are likely to contribute large amounts of both $\mathrm{N}$ and $\mathrm{P}$. The seasonal pattern of inputs also varied substantially among species due to the timing of litterfall and magnitude of potential nutrient leaching among litter types, and pulses of high leaching potential did not always correspond with large litterfall mass (Fig. 4c; CAP, PP, RO). Our results identify both 
seasonal variation in nutrient fluxes within species and seasonal variation among species that could contribute to an extended period of nutrient inputs from the urban forest. For example, across the 10 species in our study, blossoms dropped any time from April to mid-June, leaf litter fell between August and mid-December, and at least one of the species was dropping litterfall during 36 of the 38 weeks of the collection season.

Urban forests are diverse (Morgenroth et al. 2016), and community composition is structured by a range of social and economic factors (Avolio et al. 2015, 2018). Spatial variation in community composition could lead to spatial variation in the magnitude of nutrient inputs and the timing of those inputs. New planting initiatives have the potential to shift current tree diversity (Greene and Millward 2016), yet these programs rarely consider the role of trees as sources of nutrient pollution to urban ecosystem (Pincetl et al. 2013). Variation in nutrient leaching potential among species can be large; therefore, incorporating this information into the selection of trees for urban areas could have a meaningful impact on urban nutrient budgets and aquatic nutrient pollution.

Current species recommendations for street tree plantings often consider hardiness, maintenance costs (e.g., "messy" litterfall or shallow roots which damage sidewalks and roads), and tree form, but our study shows that species diversity of street trees can also influence water quality outcomes. Norway Maple with its large sprawling canopy, abundance of litterfall, and high leaching potential in both $\mathrm{N}$ and $\mathrm{P}$ make it a poor street tree recommendation, particularly as its leaf leaching potential increases with crushing. Interestingly, we found a species native to this area, Honeylocust, leached only moderate amounts of nutrients despite their association with $\mathrm{N}$-fixing bacteria. The variation in leaching potential across species brings to the forefront the need to consider proximity to impervious surface and connection to the stormwater system when planning and planting a diversity of trees in promotion of a healthy urban forest.

\section{Challenges in scaling up laboratory leaching estimates}

Urban environments are complex, and litter leaching in the field does not happen under controlled conditions (Marsalek 2003; Duan et al. 2014). Stormwater is a complex chemical mixture (Kaushal et al. 2018), with components that can both inhibit and stimulate decomposition and leaching. Components such as salt can decrease leaching rates. Yet, it is difficult to predict how the effects of a single component will translate to actual field leaching because other stormwater components, such as nutrients, could stimulate decomposition and leaching (Kominoski et al. 2015). This complexity may explain why we found no differences in leaching between stormwater and DI treatments. Similarly, while most leaching studies use intact leaves, pedestrian and vehicle traffic (including maintenance vehicles) contribute to the physical breakdown of leaf litter in urban gutters (Wang et al. 2020). While physical crushing increased leaching rates, the effects were inconsistent among species, challenging our ability to scale up laboratory studies or make assumptions about how laboratory leaching rates may translate to the field.

Another challenge for scaling up laboratory leaching estimates is the ephemeral nature of urban runoff. While $24 \mathrm{~h}$ of continual stormwater gutter flow might be more rare in this region, winter and spring snowmelt and ponding in stormwater infrastructure would more frequently lead to such conditions. Leaching requires litter drop to coincide with gutter flow, and as a result, how the urban forest community translates to actual nutrient inputs will depend on the temporal alignment of litterfall with wet- and dry-weather flows, as well as the duration of flow. Previous studies have identified pulses of nutrients in stormwater associated with litterfall (Selbig 2016; Janke et al. 2017), but further research is needed to characterize the effects of litter type and species composition on surface water nutrient concentrations.

Finally, fully scaling up laboratory leaching to watershed estimates of nutrient inputs requires information about the identity, location, and size of urban trees throughout the urban forest. Many current tree inventories only include citymanaged street trees (Nielsen et al. 2014; Morgenroth et al. 2016), neglecting nearby residential trees that may overhang city streets. Litterfall from both types of trees is likely captured and transported via stormwater infrastructure, but we lack a comprehensive understanding of forest diversity when it comes to residential trees (Hill et al. in prep). We were able to estimate city-scale nutrient fluxes because we had access to species diversity and canopy cover datasets, but those are not commonly available. Recent steps in remote sensing capabilities may assist with species identification of residential trees (Zhang and Qiu 2012; Hartling et al. 2019); however, accurately estimating litterfall of all litter types within the urban tree community is a problem that would persist. Given the variability of tree size and spatial patterns of planting, both locally and regionally, beginning to compile such datasets will improve initial estimates.

\section{Conclusion}

In addition to canopy cover (Janke et al. 2017), community composition and litterfall type are important factors affecting potential dissolved nutrient and carbon pulses. The large variation in leaching potential (up to 15 times) among litter types and species highlights the need to closely consider all litterfall contributions when creating urban nutrient 
budgets and developing maintenance programs. Translating from potential to actual leaching rates requires further understanding of when litterfall and water are simultaneously present in our storm systems. Litterfall presence is driven largely by plant phenology, but urban maintenance practices and overwatering and irrigation can lead to less predictable flows and nutrient pulsing. The timing of blossoms as springtime organic matter inputs coupled with a lack of targeted maintenance programs for non-leaf litterfall emphasizes the disproportionately large role blossoms may contribute to nutrient pollution in urban waters. Urban trees provide countless benefits to cities and urban residents (Schroeder 2011; Loughner et al. 2012; Armson et al. 2012; Livesley et al. 2016); understanding and quantifying leaching potential from seasonal litterfall is an important step in minimizing the environmental costs of the urban forest and promoting sustainable urban development and infrastructure.

Supplementary information The online version contains supplementary material available at https://doi.org/10.1007/s11252-022-01217-8.

Acknowledgements The authors would like to acknowledge the help and support of the Socio-Eco-Hydrology lab at ISU, including Sarah Stalder, Carolyn Macek, Alyssa Millard, Kyndra Hawkes, and Dane Buck. Additional thanks to Hannah Sanger and Jenna Dohman at the City of Pocatello for funding, cooperation, and support.

Authors contributions SH designed the study, collected and analyzed the data, and prepared the manuscript. RH designed the study, analyzed data, and prepared the manuscript. RN collected data. JG contributed to statistical analyses and manuscript preparation. BF and RH collected, analyzed, and prepared the data on salt leaching. KR provided consultation and data analysis in preparing the manuscript.

Funding This research was supported by research grants from the City of Pocatello, Idaho, the Department of Biological Sciences at Idaho State University, and the Center for Ecological Research and Education also at Idaho State University.

Availability of data and material Data available upon request.

Code availability Code available upon request.

\section{Declarations}

Conflicts of interest None.

\section{References}

Abelho M, Graça MAS (1996) Effects of eucalyptus afforestation on leaf litter dynamics and macroinvertebrate community structure of streams in Central Portugal. Hydrobiologia 324:195-204

Armson D, Stringer P, Ennos AR (2012) The effect of tree shade and grass on surface and globe temperatures in an urban area. Urban For Urban Green 11:245-255

Avolio ML, Pataki DE, Pincetl S, Gillespie TW, Jenerette GD, McCarthy HR (2015) Understanding preferences for tree attributes: the relative effects of socio-economic and local environmental factors. Urban Ecosyst 18:73-86

Avolio ML, Pataki DE, Trammell TLE, Endter-Wada J (2018) Biodiverse cities: the nursery industry, homeowners, and neighborhood differences drive urban tree composition. Ecol Monogr $88: 259-276$

Baker LA (2014) Users manual: Quantifying removal of solids and nutrients in street sweeping

Bates D, Machler M, Bolker B, Walker S (2015) Fitting Linear MixedEffects Models Using \{lme4\}. J Stat Softw 67:1-48

Bechtold HA, Marcarelli AM, Baxter CV, Inouye RS (2012) Effects of $\mathrm{N}, \mathrm{P}$, and organic carbon on stream biofilm nutrient limitation and uptake in a semi-arid watershed. Limnol Oceanogr 57:1544-1554

Benfield EF (1997) Comparison of Litterfall Input to Streams. J N Am Benthol Soc 16:104-108

Bratt AR, Finlay JC, Hobbie SE, Janke BD, Worm AC, Kemmitt KL (2017) Contribution of Leaf Litter to Nutrient Export during Winter Months in an Urban Residential Watershed. Environ Sci Technol 51:3138-3147

Cobley LAE, Pataki DE (2019) Vehicle emissions and fertilizer impact the leaf chemistry of urban trees in Salt Lake Valley, UT. Environ Pollut 254:112984

Cochero J, Licursi M, Gómez N (2017) Effects of pulse and press additions of salt on biofilms of nutrient-rich streams. Sci Total Environ 579:1496-1503

Cowen WF, Lee GF (1973) Leaves as source of phosphorus. Environ Sci Technol 7:853-854

da Silva JP, Martínez A, Gonçalves AL, Bärlocher F, Canhoto C (2021) Fungal richness does not buffer the effects of streams salinization on litter decomposition. Ann Limnol Int J Lim 57

Dorney JR (1986) Leachable and total phosphorous in urban street tree leaves. Water Air Soil Pollut 28:439-443

Duan S, Delaney-Newcomb K, Kaushal SS, Findlay SEG, Belt KT (2014) Potential effects of leaf litter on water quality in urban watersheds. Biogeochemistry 121:61-80

Essaid HI, Kuwabara JS, Corson-Dosch NT, Carter JL, Topping BR (2021) Evaluating the dynamics of groundwater, lakebed transport, nutrient inflow and algal blooms in Upper Klamath Lake, Oregon, USA. Sci Total Environ 765:142768

Fini A, Frangi P, Faoro M, Piatti R, Amoroso G, Ferrini F (2015) Effects of different pruning methods on an urban tree species: A four-year-experiment scaling down from the whole tree to the chloroplasts. Urban For Urban Green 14:664-674

Fork ML, Blaszczak JR, Delesantro JM, Heffernan JB (2018) Engineered headwaters can act as sources of dissolved organic matter and nitrogen to urban stream networks: Engineered headwaters can act as sources of DOM and N. Limnol Oceanogr Lett 3:215-224

Fox J, Weisberg S (2019) An (R) Companion to applied regression. Sage, Third

Greene CS, Millward AA (2016) The legacy of past tree planting decisions for a city confronting emerald ash borer (Agrilus planipennis) invasion. Front Ecol Evol 4

Groffman PM, Law NL, Belt KT, Band LE, Fisher GT (2004) Nitrogen fluxes and retention in urban watershed ecosystems. Ecosystems 7

Hartling S, Sagan V, Sidike P, Maimaitijiang M, Carron J (2019) Urban tree species classification using a WorldView-2/3 and LiDAR data fusion approach and deep learning. Sensors 19:1284

Herms DA, McCullough DG (2014) Emerald ash borer invasion of North America: History, biology, ecology, impacts, and management. Annu Rev Entomol 59:13-30

Hobbie SE, Baker LA, Buyarski C, Nidzgorski D, Finlay JC (2014) Decomposition of tree leaf litter on pavement: implications for urban water quality. Urban Ecosyst 17:369-385

Hobbie SE, Finlay JC, Janke BD, Nidzgorski DA, Millet DB, Baker LA (2017) Contrasting nitrogen and phosphorus budgets in urban 
watersheds and implications for managing urban water pollution. Proc Natl Acad Sci 114:4177-4182

Howarth RW, Anderson DB, Cloern JE, Elfring C, Hopkinson CS, Lapointe B, Malone T, Marcus N, McGlathery K, Sharpley AN, Walker D (2000) Nutrient pollution of coastal rivers, bays, and seas. Issues Ecol 1-16

Idaho Department of Lands (2018) Idaho urban tree canopy assessment

Janke BD, Finlay JC, Hobbie SE (2017) Trees and streets as drivers of urban stormwater nutrient pollution. Environ Sci Technol 51:9569-9579

Jara MC, Henry M, Réjou-Méchain M, Wayson C, Zapata-Cuartas M, Piotto D, Guier FA, Lombis HC, López EC, Lara RC, Rojas KC, Pasquel JDÁ, Montoya ÁD, Vega JF, Galo AJ, López OR, Marklund LG, Fuentes JMM, Milla F (2015) Guidelines for documenting and reporting tree allometric equations. Ann for Sci 72:763-768

Kaushal SS, Gold AJ, Bernal S, Johnson TAN, Addy K, Burgin A, Burns DA, Coble AA, Hood E, Lu Y, Mayer P, Minor EC, Schroth AW, Vidon P, Wilson H, Xenopoulos MA, Doody T, Galella JG, Goodling P, Haviland K, Haq S, Wessel B, Wood KL, Jaworski N, Belt KT (2018) Watershed 'chemical cocktails': forming novel elemental combinations in Anthropocene fresh waters. Biogeochemistry 141:281-305

Kominoski JS, Rosemond AD, Benstead JP, Gulis V, Maerz JC, Manning DWP (2015) Low-to-moderate nitrogen and phosphorus concentrations accelerate microbially driven litter breakdown rates. Ecol Appl 25:856-865

Lawrence BT, Melgar JC (2018) Variable fall climate influences nutrient resorption and reserve storage in young peach trees. Front Plant Sci 9

Lenth R (2020) emmeans: Estimated marginal means, aka least-squares means

Livesley SJ, McPherson GM, Calfapietra C (2016) The urban forest and ecosystem services: impacts on urban water, heat, and pollution cycles at the tree, street, and city scale. J Environ Qual 45:119

Loughner CP, Allen DJ, Zhang D-L, Pickering KE, Dickerson RR, Landry L (2012) Roles of urban tree canopy and buildings in urban heat island effects: parameterization and preliminary results. J Appl Meteorol Climatol 51:1775-1793

MacKenzie RA, Wiegner TN, Kinslow F, Cormier N, Strauch AM (2013) Leaf-litter inputs from an invasive nitrogen-fixing tree influence organic-matter dynamics and nitrogen inputs in a Hawaiian river. Freshw Sci 32:1036-1052

Marsalek J (2003) Road salts in urban stormwater: an emerging issue in stormwater management in cold climates. Water Sci Technol 48:61-70

Martínez A, Barros J, Gonçalves AL, Canhoto C (2020) Salinisation effects on leaf litter decomposition in fresh waters: Does the ionic composition of salt matter? Freshw Biol 65:1475-1483

McGeehan SL, Naylor DV (1988) Automated instrumental analysis of carbon and nitrogen in plant and soil samples. Commun Soil Sci Plant Anal 19:493-505

McHale MR, Burke IC, Lefsky MA, Peper PJ, McPherson EG (2009) Urban forest biomass estimates: is it important to use allometric relationships developed specifically for urban trees? Urban Ecosyst 12:95-113

McPherson EG, van Doorn NS, Peper PJ (2016) Urban tree database and allometric equations. Page PSW-GTR-253. U.S. Department of Agriculture, Forest Service, Pacific Southwest Research Station, Albany, CA

McPherson EG, Peper PJ (2012) Urban tree growth modeling 9

Metson GS, Iwaniec DM, Baker LA, Bennett EM, Childers DL, Cordell D, Grimm NB, Grove JM, Nidzgorski DA, White S (2015) Urban phosphorus sustainability: Systemically incorporating social, ecological, and technological factors into phosphorus flow analysis. Environ Sci Policy 47:1-11

Meyer JL (1980) Dynamics of phosphorus and organic matter during leaf decomposition in a forest stream. Oikos 34:44

Morgenroth J, Östberg J, Konijnendijk van den Bosch C, Nielsen AB, Hauer R, Sjöman H, Chen W, Jansson M (2016) Urban tree diversity-Taking stock and looking ahead. Urban For Urban Green 15:1-5

Nielsen AB, Östberg J, Delshammar T (2014) Review of urban tree inventory methods used to collect data at single-tree level 17

Pincetl S, Gillespie T, Pataki DE, Saatchi S, Saphores J-D (2013) Urban tree planting programs, function or fashion? Los Angeles and urban tree planting campaigns. GeoJournal 78:475-493

Pitt RE, Maestre A (2005) Stormwater quality as described in the National Stormwater Quality Database (NSQD) 8

Pozo J, González E, Díez JR, Molinero J, Elósegui A (1997) Inputs of particulate organic matter to streams with different riparian vegetation. J N Am Benthol Soc 16:602-611

R Core Team (2020) R: The R project for statistical computing. https:// www.r-project.org/

Ray A (2010) Portneuf River TMDL revision and addendum. TMDL, Idaho Department of Environmental Quality, pp 1-415

Schroeder HW (2011) Does beauty still matter? Experiential and utilitarian values of urban trees. In trees, people and the built environment. Proceedings of the Urban Trees Research Conference 13-14 Apr 2011; Edgbaston, Birmingham, UK. Institute of Chartered Foresters 159-165

Selbig WR (2016) Evaluation of leaf removal as a means to reduce nutrient concentrations and loads in urban stormwater. Sci Total Environ 571:124-133

Singh KP, Singh PK, Tripathi SK (1999) Litterfall, litter decomposition and nutrient release patterns in four native tree species raised on coal mine spoil at Singrauli, India. Biol Fertil Soils 29:371-378

Templer PH, Toll JW, Hutyra LR, Raciti SM (2015) Nitrogen and carbon export from urban areas through removal and export of litterfall. Environ Pollut 197:256-261

US Census Bureau (2018) American community survey. https://www. census.gov/programs-surveys/acs/data.html

Wallace TA, Ganf GG, Brookes JD (2008) A comparison of phosphorus and DOC leachates from different types of leaf litter in an urban environment. Freshw Biol 53:1902-1913

Walsh CJ, Roy AH, Feminella JW, Cottingham PD, Groffman PM, Morgan RP (2005) The urban stream syndrome: current knowledge and the search for a cure. J N Am Benthol Soc 24:706

Wang T, Thompson AM, Selbig WR (2020) Leachable phosphorus from senesced green ash and Norway maple leaves in urban watersheds. Sci Total Environ 743:140662

Wang YP, Houlton BZ, Field CB (2007) A model of biogeochemical cycles of carbon, nitrogen, and phosphorus including symbiotic nitrogen fixation and phosphatase production. Glob Biogeochem Cycles 21

Wawrzynski RP, Ascerno ME (1989) Ash flower gall: within tree distribution and chemical management. J Arboric 15:4

Wickham H (2016) ggplot2: Elegant graphics for data analysis. Springer-Verlag, New York

Zhang C, Qiu F (2012) Mapping individual tree species in an urban forest using airborne lidar data and hyperspectral imagery. Photogramm Eng Remote Sens 78:1079-1087

Publisher's note Springer Nature remains neutral with regard to jurisdictional claims in published maps and institutional affiliations. 